\title{
EFFECTS OF UTILIZATION DEVELOPMENTS AND TRENDS ON THE FOREST ${ }^{1}$
}

\author{
BY G. R. SONLEY ${ }^{2}$
}

Forest utilization is that branch of forestry concerned with the operation of harvesting and marketing the forest crop and other resources of the forestForest Terminology.

Since the panel speakers selected represent a considerable range, geographically, I will describe only those developments and trends which are evident within the district of which I am familiar, namely, Northwestern Ontario and more particularly within our own operation.

Developments and trends will be discussed under Planning, Increased Use of Species, Mechanization of Logging, Integrated Operations and Administration. Because many of the developments are inter-related, I will describe the developments and then comment on the effects of these on the forest.

\section{Planning}

It is safe to say that foresters over the last 50 years have proven their value in the forest operating companies. Many of the older foresters are now in the ranks of management and as such do not have to be sold on the necessity of long term planning in forest management. The net result is that more and more foresters are being employed and more and more forestry principles are being applied to the management of the forest. Some of the developments resulting from planning are year-round employment, permanent camps, and roads.

Logging has in the past been regarded in Eastern Canada as a seasonal occupation being carried on during the fall and winter. In some sections adjacent to a large farming population where excess labor is available in the winter, this is a commendable practice. However, in the area around the Lakehead, the supply of excess farm labor is a very small proportion of the total requirements. Most woods workers depend on woods employment for their entire livelihood. This factor, along with a high demand for pulpwood and a short labor market, has been responsible for the trend toward year-round employment.

With the standard of housing woods workers increasing, and the realization that roads can be built and men taken to work in buses, has come the idea of permanent camps. This has been hastened by the fact that many woods workers are married and wish to live with their families. This has resulted in the forest being organized into working circles and a forest community being established to harvest the allowable cut from each of these working circles.

In our operation all the company production is by six such forest communities (formerly called camps) with allowable cuts varying from 25 to 55,000 cords. The number of family units in these forest communities varies

\footnotetext{
${ }^{1}$ A paper presented at the 48 th Annual Meeting of the Canadian Institute of Forestry, held at Chicoutimi, Quebec, October 2 - 5, 1956.

${ }^{2}$ Chief Forester, Marathon Corporation of Canada Ltd.
} 
from three to thirty. Of the six communities, three have general stores and post offices and four have schools-one with two rooms. Logging has changed from a nomadic to a permanent basis.

Roads are another evidence of both mechanization and planning and could properly be discussed under both headings. Under the heading of Planning, it can be said that with a short-term view roads can be built with only the thought of extracting the wood adjacent to the road or a longer term view taken where an adequate system of roads can be planned for opening the limit and the extraction of the timber can be co-ordinated with the development. With long-term planning, if the roads are properly located they should serve many rotations and hence the extraction of the present stand of timber should come secondary to adequate road planning. There is evidence that the long-term view is becoming more popular.

\section{INCREASE IN THE USE OF SPECIES}

You are all familiar with the pattern of species utilization: Sawmills were the first industry established and their demand was first white and red pine, later spruce and, in recent years, jack pine. Pulp mills first quantity demand was spruce, preferably black, later broadened to include some balsam and still later some jack pine. Now, following the lead of the mills in the Lake States, hardwoods are being used in ever-increasing proportion. On our limit the mill can use all species in the proportion they form of our present inventory. The Woods Division has not solved the problem of delivering all species, but can and does deliver all aspen in the proportion it forms of our inventory, and is shipping some birch this year by rail. I have no doubt that access roads would materially increase the utilization of birch and balsam poplar.

\section{Mechanization of Logging}

The logging industry is probably the most backward in realizing the advantage of power equipment and adopting it to its use. However, during the last war when there was a definite shortage of labor, some effort was made to increase the output per man and some thought was given to mechanization of the industry.

The bulldozer has had greatest influence on the harvesting of the crop and was the first to be universally adopted. With it roads are built, and roads do appear to be one of the most important keys to the practice of all forestry. Trucks came with the bulldozer.

When we consider the cutting and movement of wood from the stump to the mill, the power saw is probably the latest tool to be universally adopted, as it has been during the last three or four years in our area. Other companies have gone further and experimented with mechanical means of taking the wood from the stump to the mill. These experiments have followed the usual patterns of handling the wood in bundles, tree lengths or whole trees by tractors, arches, sloops or cables. Most hauling is now done on truck bodies or semi-trailers. All pulpwood produced on our limits during the year 1951-52 and thereafter has been handled by cable. 
projects which were impossible with other types of employee, and will have a very beneficial effect on forest management over the long term.

\section{EFFECTS OF ROADS}

When thinking of roads, I believe that they are an index to the intensity of forest management (including protection) which can be accomplished. Forest industries are unique in that they have to build their own roads. There is only so much profit from operating and it would appear that the profit from the first crop will have to go into opening the limit, and road construction will probably get the largest portion. However, if these roads are properly planned, they can be used in the second rotation for more intensive utilization; - for example, in mixed stands the faster growing species can be logged first, thinnings can be made, fail areas, if any, can be planted, insect infestations can be dealt with and fires can be reached and extinguished. Without roads none of these is possible.

You will note I have included protection under forest management, and to me that is where it belongs. As soon as the forest comes under intensive management, protection will be a minor problem and, conversely, protection can never be satisfactory until there is fairly intensive management. Therefore, although building roads to harvest the forest may not be very spectacular, I believe the foundation is being laid for intensive forest management in the future.

\section{EFFECT OF INCREASED USE OF SPECIES}

It goes without saying that very little can be accomplished in the way of management if there is a demand for only one or two species. Therefore, the trend of utilization of a greater diversity of species will give the forester much more latitude in management. It will increase the yield per acre and reduce the area classified as unmerchantable forest due to species composition.

\section{Effect of Mechanization}

I have spoken on roads. Here I will discuss mechanization of felling, limbing and hauling.

The effect of the power saw is the low stumps. This increases the volume of wood per tree utilized. The low stumps will also allow tractors and other machinery to travel through the cut-over areas if there is a need. It will certainly make possible the use of machines for scarifying the soil and disposal of slash. It is generally accepted that scarification is beneficial for seed-bed treatment, both for germination of seed and to increase root sucker growth. Cut and pile in strips and haul in the winter causes the least soil disturbance, whereas those systems which skid tree lengths in summer do most. I would judge that skidding whole trees would not be as beneficial as tree lengths, as the trees would skid on the branches and the soil would not be too much disturbed. You will note I have referred to summer and winter operations. Summer cutting and skidding is very beneficial for seed-bed preparation. When considering fire control, the cut and pile in strips is probably the worst condition; cutting and skidding in full trees is probably the best. However, the cut and skid in tree lengths is good, as the limbs and tops are scattered evenly over the area and a very large per cent of the slash is crushed 
and broken by skidding. Thus no slash is left in piles, but all is in contact with the ground where it presents no fire hazard after the annuals leaf out in the spring. When considering jack pine, the slash is broken up and the cones are brought down near the soil where the temperature is adequate to open them. The scarified soil makes a good germinating bed. When aspen is yarded in tree lengths the soil is disturbed, which activates root suckering. Thus, for management of both aspen and jack pine, clear cutting and summer skidding in tree length meets the silvicultural requirements for re-establishment of stand.

\section{EFFECT OF INTEGRATED OPERATIONS}

I cannot see that this will have any effect on the forest except where it increases the species being utilized. It has no influence on the forest whether the $\log$ is manufactured into ties, lumber or pulp. Integration is an economic problem and when it is economically possible there is no doubt that it will grow. When there is no economic advantage it is unfair to make one industry subsidize another.

\section{EFFECT OF Administration}

The revised Crown Timber Act and its regulation have done something to focus attention on management. It has enforced the taking of forest inventories and probably longer range planning than was done previously, especially by the smaller companies. However, there is nothing new involved -no attempt to create an incentive to forest management, only the application of a penalty if certain practices are not followed, and I suspect most of the practices have to do with the collection of dues, not the practice of forestry. While it may be nice to see complete utilization with low stumps and small tops, it is difficult to justify penalties on the basis of waste when only $25 \%$ of the allowable cut is being harvested in our forest district. Is it worse to have wood fibre decay in the form of a high stump, large top, than a standing tree in an overmature and uncut forest?

In closing, I endorse most heartily the brief of the C.I.F. to the Gordon Commission. I am sorry to say that I have seen no trends of the administration to create an atmosphere where it is practical to practice forest management. Until we do see such trends, I am very pessimistic concerning any major advance in forest management. 